Gut, 1970, 11, 567-575

\title{
The effect on jejunal mucosa of withdrawing and adding dietary gluten in cases of idiopathic steatorrhoea
}

\author{
D. J. POLLOCK ${ }^{2}$, R. E. NAGLE 3 , K. N. JEEJEEBHOY 4 , A ND N. F. COGHILL \\ From the West Middlesex Hospital, Isleworth, Middlesex
}

SUMMARY Biopsy studies of the jejunal mucosa in patients with idiopathic steatorrhoea after periods on a gluten-free diet showed that the epithelium improved quickly in respect of surface cell height, mucosal thickness, and mitosis count, and more slowly in respect of villous height and width. In no case was recovery complete in every particular. Appearances seen through the dissecting microscope improved slowly and incompletely.

Gluten loading after a period on a gluten-free diet partially reversed some of these mucosal changes in as short a time as five to seven days.

Measuring such changes may help to hasten the diagnosis in some patients with suspected gluten-sensitive enteropathy in whom there is otherwise difficulty in assessing the clinical response to a gluten-free diet. The histological response of the jejunum to a glutenfree diet and to subsequent gluten loading may help to clarify the aetiological relationship between carcinoma and jejunal mucosal atrophy.

The histological appearance of the jejunal mucosa in idiopathic steatorrhoea (adult coeliac disease, non-tropical sprue, gluten-sensitive enteropathy), first adequately described by Paulley (1954) and Doniach and Shiner (1957), is now well known. Opinions have varied about the degree of histological response to the exclusion of dietary gluten, and the proportion of patients in whom such responses may occur (Shiner and Doniach, 1958; Anderson, 1960; Doniach and Shiner, 1960; Rubin, 1960 and 1961; Yardley, Bayless, Norton, and Hendrix, 1962; Galen, 1962; Bolt, Parrish, French, and Pollard 1964; MacDonald, Brandborg, Flick, Trier, and Rubin, 1964; Stewart, Pollock, Hoffbrand, Mollin, and Booth, 1967).

The purpose of this paper is to show that the histological appearance of the jejunal mucosa does improve in patients with idiopathic steatorrhoea when gluten is withdrawn from their diet

${ }^{1}$ Address requests for reprints to Dr N. F. Coghill, West Middlesex Hospital.

Received for publication 17 February 1969. although it seldom reverts to normal. This improvement is quickly reversed when gluten is eaten.

\section{Patients Studied}

Seventeen patients (six men and 11 women) were studied. Their ages ranged from 19 to 70 years. All but one of the patients are in good health? four to 10 years after their first jejunal biopsy. The exception (case 12, aged 50) has carcinoma $\Phi_{\infty}$ of the larynx; she has been known to have? steatorrhoea for 22 years and her history goes back to childhood.

The diagnosis of idiopathic steatorrhoea was $\stackrel{\odot}{\oplus}$ based in each patient on exclusion of other $\stackrel{2}{\circ}$ known causes of steatorrhoea and on the presence of clinical, laboratory, and radiological manifes- 8

2Present address: Institute of Pathology, The London Hospital, Whitechapel, E1.

${ }^{3}$ Present address: Queen Elizabeth Hospital, Birmingham. "Present address: Department of Medicine, University of Toronto," Canada. 
tations of idiopathic steatorrhoea. On biopsy the jejunal mucosa was abnormal in every case.

Fifteen patients were studied before and after a gluten-free diet (Table I) and eight were studied on a gluten-free diet and after gluten loading (Table III).

\section{Materials and Methods}

Biopsy of the upper jejunum just beyond the duodeno-jejunal junction with a Crosby capsule under fluoroscopic control showed an abnormal mucosa in each of the 15 cases in which it was performed before treatment. Jejunal biopsies were obtained in 16 patients while they were on a gluten-free diet (Table I) and in eight patients after subsequent loading with gluten (Table III). Each biopsy specimen was mounted, mucosal surface uppermost, on a piece of duplicating paper, and promptly fixed in formol-saline and examined at once with a dissecting microscope under $\times 10$ magnification (Holmes, Hourihane, and Booth, 1961). The mucosa in the biopsy specimens was classified as follows: predominance of finger-like villi; predominance of leaf-like villi; convoluted ridges (partial villous atrophy, the initial state in three patients); flat (subtotal villous atrophy, the initial state in 14 patients). Sections were cut at $90^{\circ}$ to the surface, and stained with haematoxylin and eosin for the measurements and by the Feulgen method for mitosis counts. Measurements of the biopsy specimens were made by one of us (D.J.P.) without knowledge of the patients' clinical details or their diet. An eyepiece micrometer was used to measure villous height and width, mucosal thick- $\Omega$ ness, and epithelial surface cell height. In those patients with partial villous atrophy the ridges appeared in the sections as villous-like projections and were measured as such. At least 10 villi were measured in an area in which the plane of section was perpendicular to the surface. Villous height was taken to be the distance from the tip of the villus to the bottom of the crypt, and villous width was measured at the widest point of the villus above the base. Measurement of villi was considered impossible in the absence of 10 suitable villi. Measurements of surface cell height were taken near the tips of villi when present or from the surface as distant as possible from the openings of the crypts. Twenty suitable cells, chosen because of centrally placed basal nuclei indicating perpendicular section, were measured in each case. The mucosal thickness was measured from the mucosal aspect of the muscularis mucosae to the openings of the crypts. Epithelial mitosis counts included a thousand consecutive cells from the bases of crypts to the tips of the villi, or along the surface when villi were absent. Only easily recognized cells in mitosis were recorded. In a few cases no suitable area for mitosis counts could be found. An estimate was made of the number and character of the inflammatory cells both in the mucosa and passing through the surface epithelium. The following values for the different measurements, obtained

\begin{tabular}{|c|c|c|c|c|c|c|c|c|c|c|c|c|c|c|c|c|}
\hline \multirow{2}{*}{$\begin{array}{l}\text { Histological Features and } \\
\text { Treatment Period }^{1}\end{array}$} & \multicolumn{16}{|c|}{ Case Numbers } \\
\hline & 1 & 2 & 3 & 4 & 5 & 6 & 7 & 8 & 9 & 10 & 11 & 12 & 13 & 14 & 15 & 17 \\
\hline \multicolumn{17}{|l|}{$\begin{array}{l}\text { Surface cell height }(\mu) \\
\text { Before treatment }\end{array}$} \\
\hline Before treatment & - & $\begin{array}{c}(14 \cdot 1) \\
18 \cdot 6\end{array}$ & $17 \cdot 7$ & 14.9 & $17 \cdot 8$ & $12 \cdot 5$ & $17 \cdot 8$ & $19 \cdot 2$ & $17 \cdot 3$ & $16 \cdot 3$ & $25 \cdot 9$ & $4 \cdot 8$ & $20 \cdot 1$ & $21 \cdot 6$ & 18.9 & $23 \cdot 5$ \\
\hline Period I & & $25 \cdot 1$ & & & & & & $27 \cdot 4$ & & & $27 \cdot 8$ & $16 \cdot 8$ & $26 \cdot 4$ & $32 \cdot 5$ & $24 \cdot 3$ & $24 \cdot 8$ \\
\hline Period II & $(24 \cdot 5)$ & $33 \cdot 0$ & $\begin{array}{c}(24 \cdot 1) \\
24 \cdot 4\end{array}$ & & & & $24 \cdot 5$ & & $24 \cdot 5$ & & & & & $34 \cdot 0$ & $18 \cdot 4$ & 202 \\
\hline Period III & $\begin{array}{l}(27 \cdot 4) \\
(25 \cdot 0) \\
(21 \cdot 6)\end{array}$ & & & $\begin{array}{l}24 \cdot 5 \\
(24 \cdot 9)\end{array}$ & $31 \cdot 0$ & $22 \cdot 8$ & & & & $25 \cdot 0$ & & & & & & \\
\hline \multicolumn{17}{|l|}{ Mucosal thickness $(\mu)$} \\
\hline Before treatment & 一 & $\begin{array}{c}(288) \\
391\end{array}$ & 270 & 336 & 225 & 338 & 242 & 264 & 444 & 268 & 216 & 507 & 451 & 377 & 291 & 239 \\
\hline $\begin{array}{l}\text { Period I } \\
\text { Period II }\end{array}$ & (168) & $\begin{array}{l}304 \\
156\end{array}$ & (306) & & & & 122 & 258 & 300 & & 271 & 371 & 393 & $\begin{array}{l}275 \\
182\end{array}$ & 228 & $\begin{array}{l}252 \\
308\end{array}$ \\
\hline & & & 116 & & & & & & & & & & & & & \\
\hline Period III & $\begin{array}{l}(151) \\
(112) \\
(156)\end{array}$ & & & $\begin{array}{c}172 \\
(158)\end{array}$ & 120 & 210 & & & & 122 & & & & & & \\
\hline $\begin{array}{l}\text { Mitosis count } \\
\text { Before treatment }\end{array}$ & - & $\begin{array}{l}\text { Not done } \\
1.4\end{array}$ & Not done ${ }^{2}$ & $2 \cdot 5$ & $2 \cdot 1$ & $2 \cdot 9$ & $1 \cdot 6$ & $2 \cdot 5$ & $2 \cdot 0$ & $4 \cdot 2$ & $2 \cdot 6$ & Not done ${ }^{2}$ & $2 \cdot 0$ & 1.6 & $2 \cdot 0$ & $1 \cdot 6$ \\
\hline $\begin{array}{l}\text { Period I } \\
\text { Period II }\end{array}$ & $(1 \cdot 0)$ & $\begin{array}{l}1 \cdot 7 \\
1 \cdot 0\end{array}$ & $\begin{array}{l}(0 \cdot 8) \\
(1 \cdot 1)\end{array}$ & & & & $1 \cdot 1$ & $1 \cdot 1$ & $1 \cdot 1$ & & 0.7 & $(2 \cdot 1)$ & 1.6 & $\begin{array}{l}1 \cdot 4 \\
1 \cdot 4\end{array}$ & $\begin{array}{l}1 \cdot 3 \\
1 \cdot 8\end{array}$ & $\begin{array}{l}1 \cdot 2 \\
1 \cdot 2\end{array}$ \\
\hline Period III & $\begin{array}{l}(0 \cdot 9) \\
(1 \cdot 0) \\
(1 \cdot 2)\end{array}$ & & & $\begin{array}{c}1 \cdot 4 \\
(2 \cdot 2)\end{array}$ & $1 \cdot 2$ & $1 \cdot 1$ & & & & $1 \cdot 0$ & & & & & & \\
\hline
\end{tabular}

Table I Measurements of surface cell height, mucosal thickness, and mitosis counts before and after treatment 
in the course of another study (Stewart et al, 1967) were regarded as the normal range and correspond closely with the figures of Doniach and Shiner (1957) and of Chacko, Job, Johnson, and Baker (1961): villous height, 312-434 $\mu$; villous width, 102-146 $\mu$; surface cell height, 31·4-35.2 $\mu$ : mucosal thickness, $70-164 \mu$; mitoses per 100 cells, $0 \cdot 8-1 \cdot 3$.

Histological improvement was assessed on a five-point scale (increase in villous height and in surface cell height; decrease in villous width, in mucosal thickness, and in mitosis count), and on the dissecting microscope appearances. Deterioration was estimated on the same scale in reverse.

\section{Results}

THE EFFECT OF GLUTEN-FREF DIET

\section{Surface cell height}

Detailed changes in surface cell height are shown in Table I. Considerable improvement could occur in as little as one or two weeks (a rise from $4 \cdot 8$ to $16 \cdot 8 \mu$ in case 12 in seven days and from 21.6 to $32.5 \mu$ in case 14 in 12 days), but in other patients improvement was slight or delayed. In case 15 initial improvement after seven days $(18.9$ to $24.3 \mu)$ was followed by a fall in cell height to the pretreatment level $(18.4 \mu)$ at 113 days while the patient was supposed still to be on the diet. Surface cell height reached normal limits in only two patients (cases 2 and 14). Figures 1 and 2 show the improvement in surface cell height that occurred in case 2 after 14 weeks on a gluten-free diet.

\section{Mucosal thickness}

The changes in mucosal thickness are shown in Table I. It took longer for the mucosa to shrink than for the surface cell height to increase, although in a few patients reductions were considerable (from 451 to $393 \mu$ in case 13 in six days; from 507 to $371 \mu$ in case 12 and from 291 to $228 \mu$ in case 15 , both in seven days; from 377 to $275 \mu$ in case 14 in 12 days). In some patients shrinkage was progressive (cases 2 and 14). Figures 3 and 4 show the reduction in mucosal thickness that occurred in case 2 after 14 weeks on a gluten-free diet.

\section{Mitosis counts}

Mitosis counts fell about as rapidly, and in the $\mathrm{O}$ same number of patients, as surface cell height (Table I). There were large falls in the counts in case 15 (2.0 to 1.3 per 100 cells in seven days), in case 11 ( 2.6 to 0.7 per 100 cells in 15 days), and in case 8 ( 2.5 to 1.1 per 100 cells in 19 days). The counts varied in cases 4 and 15 at different times.

\section{Villous height and width}

Until after six weeks on a gluten-free diet there was no improvement in villous height or width (Table II). About two-thirds of the patients tested showed an increase in villous height between six

\begin{tabular}{|c|c|c|c|c|c|c|}
\hline \multicolumn{6}{|c|}{ Ranges and Averages for Treatment Periods } & \multirow[t]{3}{*}{ Normal Range } \\
\hline \multicolumn{2}{|c|}{ Pre-treatment State followed by Period I } & \multicolumn{2}{|c|}{ Pre-treatment State followed by Period II } & \multicolumn{2}{|c|}{ Pre-treatment State followed by Period III } & \\
\hline Mean & Range & Mean & Range & Mean & Range & \\
\hline $19 \cdot 1$ & $4 \cdot 8-25 \cdot 9$ & $19 \cdot 3$ & $17 \cdot 3-23 \cdot 5$ & $15 \cdot 4$ & $12 \cdot 5-17 \cdot 8$ & $31 \cdot 4-35 \cdot 2$ \\
\hline \multirow[t]{2}{*}{$25 \cdot 6$} & $16 \cdot 8-32 \cdot 5$ & 25.6 & 18.4240 & & & \\
\hline & & & & $26 \cdot 1$ & $22 \cdot 8-31 \cdot 0$ & \\
\hline 342 & 216-507 & 322 & $239-444$ & 292 & $225-338$ & $70-164$ \\
\hline \multirow[t]{2}{*}{294} & 228-393 & 218 & $116-308$ & & & \\
\hline & & & & 156 & $120-210$ & \\
\hline 1.96 & 1.4- 2.6 & $1 \cdot 7$ & 1.4- $2 \cdot 0$ & $2 \cdot 93$ & $2 \cdot 9 \cdot 4 \cdot 2$ & $\begin{array}{l}0.8-1 \cdot 3 \\
(\text { Mean: } 1 \cdot 1)\end{array}$ \\
\hline \multirow{2}{*}{$1 \cdot 29$} & $0.7-1.7$ & $1 \cdot 27$ & $1.0-1.8$ & & & \\
\hline & & & & $1 \cdot 18$ & $1.0-1.4$ & \\
\hline
\end{tabular}

Table 1-continued

1The three treatment periods after starting a gluten-free diet were: (I) 3 days to 6 weeks; (II) 6 to 36 weeks; (III) 40 to 176 weeks. The values in brackets were not used for calculating the means nor in the statistical analysis.

${ }^{2}$ No field suitable for mitosis count. 


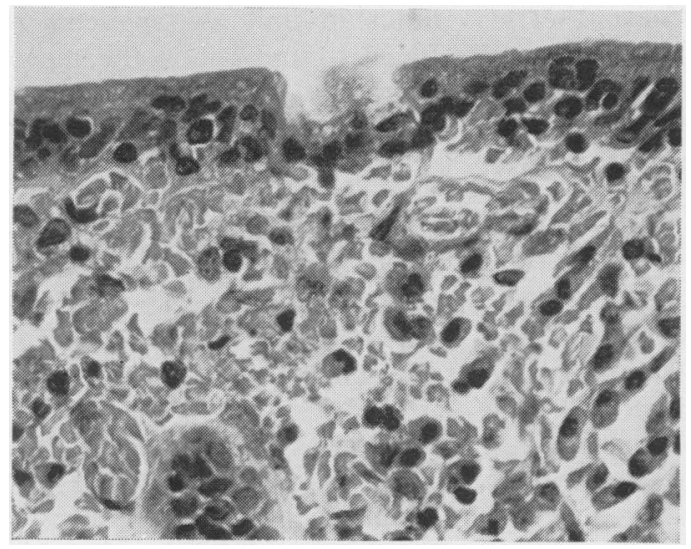

Fig. 1 Case 2 (aged 22): pretreatment biopsy specimen. Surface cells are low and darkly staining, and lymphocytes are seen passing between them. There is an infiltrate of plasma cells in the mucosa. Surface cell height $14 \cdot 1 \mu(\times 160$, haematoxylin and eosin, $5 \mu$ ).

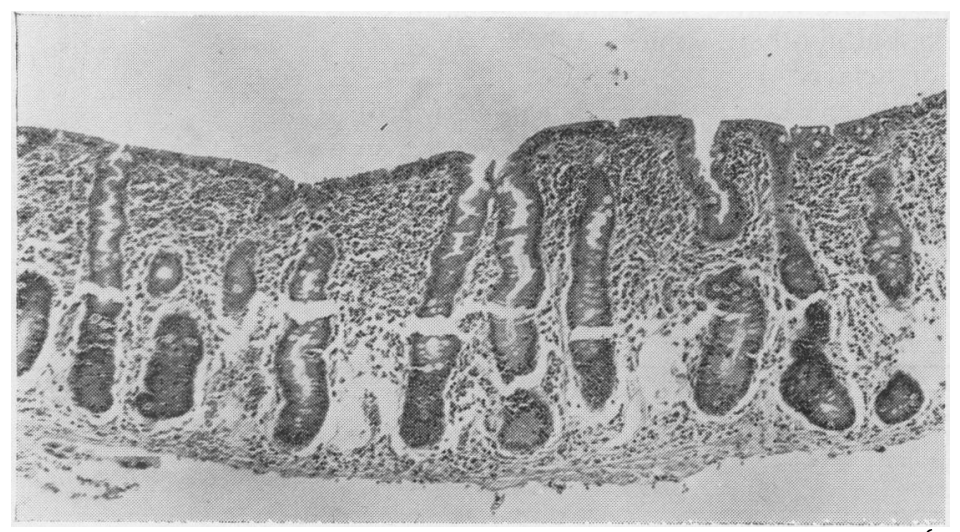

Fig. 3 Case 2: same biopsy specimen as in Figure 1. The mucosa is flat and thickened. Dissecting microscope appearance flat. Mucosal thickness $288 \mu$ $(\times 15$, haematoxylin and eosin, $5 \mu$ ).

and 36 weeks on the diet, four out of seven reaching normal values, and one more almost reaching them; and after 40 weeks all patients tested showed improvement, three out of five reaching normal values. About two-thirds of the patients tested showed decrease in villous width between six and 36 weeks on the diet, three out of seven reaching normal values, and two more almost reaching them; after $\mathbf{4 0}$ weeks all five patients tested reached normal values.

Inflammatory cells

The number of inflammatory cells in the mucosa

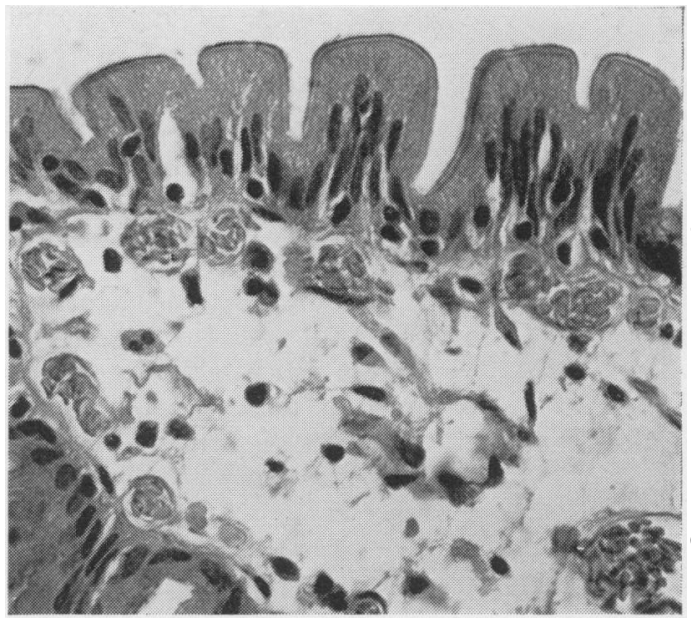

Fig. 2 Case 2: after 14 weeks on a gluten-free diet surface cells are now columnar with the brush border visible; lymphocytes and plasma cells are decreased in number. Surface cell height $33.0 \mu$, i.e., within the normal range $(\times 160$, haematoxylin and eosin, $5 \mu)$

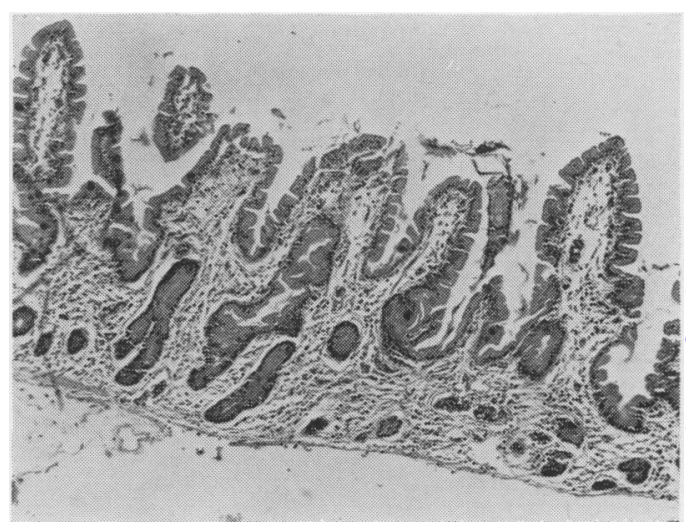

Fig. 4 Case 2: Same biopsy specimen as in Figure 2 Villi now present and mucosa thinner. Dissecting microscope appearance leaflike villi. Mucosal thickness $196 \mu$ (normal range 70-164), width $151 \mu$ (normal range, 102-146), villous height $393 \mu$ (normal range, 312-434) $(\times 15$, haematoxylin and eosin, $5 \mu)$.

and passing through the surface epithelium was $\frac{0}{\varnothing}$ difficult to measure and assessment depended on $\stackrel{\infty}{?}$ impression. No difference was seen in the number 0 of plasma cells and eosinophils in the mucosa of patients on a gluten-free diet. There appeared, $\stackrel{\Phi}{\Phi}$ however, to be a decrease in the number of $\frac{\mathbb{Q}}{\mathscr{Q}}$ lymphocytes and polymorphonuclear leucocytes passing through the surface cells even after a short period on a gluten-free diet.

Appearance of mucosal surface In nine patients the dissecting microscope? appearances of the mucosa improved: in two 
from flat to leaf-like villi, in five from flat to convoluted villi, and in two from convoluted to leaf-like villi. None of these changes took place in less than six weeks. The speed of response, or its lack, bore no relation to the ages of the patients.

\section{THE EFFECT OF GLUTEN LOADING}

\section{Surface cell height}

The effect of gluten loading on surface cell height was variable and did not depend particularly on the length of the loading period, nor the duration of the previous gluten-free diet, nor on the height of the cells before loading (Table III). However in the two instances where the surface cells had become normal there was the largest reduction in cell height after loading with gluten (cases 2 and 14). Figures 2 and 5 illustrate an example of this change. In contrast, in two other patients (cases 1 and 15) in whom the surface cell height after increasing moderately on treatment had fallen again, gluten loading produced little or no further reduction (Fig. 6).

\section{Mucosal thickness}

On gluten loading the mucosa became thicker $\vec{\circ}$ in seven patients but in one still remained within the normal range). The sequence of improvement

\begin{tabular}{|c|c|c|c|c|c|}
\hline \multirow[t]{2}{*}{ Period on Gluten-free Diet } & \multicolumn{3}{|c|}{ Histological Features of the Villi } & \multirow{2}{*}{$\begin{array}{l}\text { Decrease in } \\
\text { Mucosal Thickness }\end{array}$} & \multirow{2}{*}{$\begin{array}{l}\text { Decrease in } \\
\text { Mitosis Count }\end{array}$} \\
\hline & $\begin{array}{l}\text { Increase in } \\
\text { Height }\end{array}$ & $\begin{array}{l}\text { Increase in } \\
\text { Surface Cell } \\
\text { Height }\end{array}$ & $\begin{array}{l}\text { Decrease in } \\
\text { Width }\end{array}$ & & \\
\hline $\begin{array}{l}\text { Six days to } 3 \text { weeks (period I) } \\
\text { Six weeks to } 36 \text { weeks (period II) } \\
\text { Forty weeks to } 176 \text { weeks (period III) }\end{array}$ & $\begin{array}{l}0 / 8 \\
5 / 7 \\
5 / 5\end{array}$ & $\begin{array}{l}8 / 8 \\
5 / 7 \\
5 / 5\end{array}$ & $\begin{array}{l}0 / 8 \\
5 / 7 \\
5 / 5\end{array}$ & $\begin{array}{l}5 / 8 \\
5 / 7 \\
5 / 5\end{array}$ & $\begin{array}{l}6 / 7 \\
6 / 6 \\
5 / 5\end{array}$ \\
\hline
\end{tabular}

Table II Number of patients showing improvement in the various histological features in the jejunal mucosa biopsied at intervals after starting a gluten-free diet

The second figure in each category represents the number of patients in whom valid measurements were possible on biopsy specimens.

\begin{tabular}{|c|c|c|c|c|c|c|c|c|c|c|c|}
\hline \multirow{2}{*}{$\begin{array}{l}\text { Histological Feature and } \\
\text { Treatment State }\end{array}$} & \multicolumn{10}{|c|}{ Case Numbers } & \multirow[t]{2}{*}{ Normal Range } \\
\hline & 3 & 4 & 5 & 14 & 15 & 1 & 2 & 16 & Mean & Range & \\
\hline \multicolumn{12}{|l|}{ Surface cell height $(\mu)$} \\
\hline Before treatment & $17 \cdot 7$ & $14 \cdot 9$ & $17 \cdot 8$ & $21 \cdot 6$ & $18 \cdot 9$ & - & $\begin{array}{c}(14 \cdot 1) \\
18 \cdot 6\end{array}$ & 一 & $18 \cdot 3$ & $14 \cdot 9-21 \cdot 6$ & $31 \cdot 4-35 \cdot 2$ \\
\hline $\begin{array}{l}\text { Treated (last biopsy) } \\
\text { After gluten loading }\end{array}$ & $\begin{array}{l}24 \cdot 4 \\
24 \cdot 4\end{array}$ & $\begin{array}{l}24 \cdot 9 \\
19 \cdot 2\end{array}$ & $\begin{array}{l}31 \cdot 0 \\
25 \cdot 9\end{array}$ & $\begin{array}{l}34 \cdot 0 \\
23 \cdot 2\end{array}$ & $\begin{array}{l}18 \cdot 4 \\
18 \cdot 4\end{array}$ & $\begin{array}{l}21 \cdot 6 \\
18 \cdot 4\end{array}$ & $\begin{array}{l}33 \cdot 0 \\
19 \cdot 4\end{array}$ & $\begin{array}{l}28 \cdot 0 \\
22 \cdot 4\end{array}$ & $\begin{array}{l}26 \cdot 9 \\
21 \cdot 4\end{array}$ & $\begin{array}{l}18 \cdot 4-34 \cdot 0 \\
18 \cdot 4-25 \cdot 9\end{array}$ & \\
\hline \multicolumn{12}{|l|}{ Mucosal thickness $(\mu)$} \\
\hline Before treatment & 270 & 336 & 225 & 377 & 291 & - & $\begin{array}{c}(288) \\
391\end{array}$ & - & 315 & $225-391$ & $70-164$ \\
\hline $\begin{array}{l}\text { Treated (last biopsy) } \\
\text { After gluten loading }\end{array}$ & $\begin{array}{l}116 \\
139\end{array}$ & $\begin{array}{l}158 \\
211\end{array}$ & $\begin{array}{l}120 \\
165\end{array}$ & $\begin{array}{l}182 \\
196\end{array}$ & $\begin{array}{l}304 \\
304\end{array}$ & $\begin{array}{l}156 \\
213\end{array}$ & $\begin{array}{l}196 \\
260\end{array}$ & $\begin{array}{l}199 \\
344\end{array}$ & $\begin{array}{l}179 \\
229\end{array}$ & $\begin{array}{l}116-304 \\
139-344\end{array}$ & \\
\hline \multicolumn{12}{|l|}{ Mitosis co2nt } \\
\hline Before treatment & Not done ${ }^{1}$ & $2 \cdot 5$ & $2 \cdot 1$ & $1 \cdot 6$ & $2 \cdot 0$ & - & $\begin{array}{l}\text { Not done } \\
1.4\end{array}$ & 一 & $1 \cdot 92$ & $1 \cdot 4-2 \cdot 5$ & $\begin{array}{l}0 \cdot 8-1 \cdot 3 \\
(\text { mean: } 1 \cdot 1)\end{array}$ \\
\hline $\begin{array}{l}\text { Treated (last biopsy) } \\
\text { After gluten loading }\end{array}$ & $\begin{array}{l}1 \cdot 1 \\
1 \cdot 2\end{array}$ & $\begin{array}{l}2 \cdot 2 \\
1 \cdot 0\end{array}$ & $\begin{array}{l}1 \cdot 2 \\
1 \cdot 1\end{array}$ & $\begin{array}{l}1 \cdot 4 \\
1 \cdot 5\end{array}$ & $\begin{array}{l}1 \cdot 8 \\
2 \cdot 0\end{array}$ & $\begin{array}{l}1 \cdot 2 \\
1 \cdot 6\end{array}$ & $\begin{array}{l}1.0 \\
1.6\end{array}$ & $\begin{array}{l}1 \cdot 4 \\
1 \cdot 2\end{array}$ & $\begin{array}{l}1.41 \\
1.40\end{array}$ & $\begin{array}{l}1 \cdot 0-2 \cdot 2 \\
1 \cdot 0-2 \cdot 2\end{array}$ & \\
\hline \multicolumn{12}{|l|}{ Villous height $(\mu)$} \\
\hline $\begin{array}{l}\text { Before treatment } \\
\text { Treated (last biopsy) } \\
\text { After gluten loading }\end{array}$ & $\begin{array}{l}302 \\
379 \\
381\end{array}$ & $\begin{array}{l}A^{2} \\
276 \\
290\end{array}$ & $\begin{array}{l}292 \\
437 \\
420\end{array}$ & $\begin{array}{l}\mathbf{A} \\
\mathbf{3 5 1} \\
\mathbf{3 3 0}\end{array}$ & $\begin{array}{l}\mathbf{A} \\
\mathbf{A} \\
\mathbf{A}\end{array}$ & $\begin{array}{l}\overline{369} \\
225\end{array}$ & $\begin{array}{l}\text { A } \\
393 \\
242\end{array}$ & $\overline{\mathbf{A}}$ & $\begin{array}{l}99 \cdot 0 \\
276 \\
236\end{array}$ & $\begin{array}{l}0-302 \\
0-437 \\
0-420\end{array}$ & $312-434$ \\
\hline \multicolumn{12}{|l|}{ Villous width $(\mu)$} \\
\hline Before treatment & 164 & (A) & 196 & (A) & (A) & - & (A) & - & 180 & $\begin{array}{l}164-196 \\
\text { (if present) }\end{array}$ & $102-146$ \\
\hline Treated (last biopsy) & 115 & 110 & 134 & 153 & (A) & 127 & 151 & (A) & 132 & $\begin{array}{l}110-153 \\
\text { (if present) }\end{array}$ & \\
\hline After gluten loading & 136 & 139 & 110 & 156 & (A) & 146 & 156 & (A) & 141 & $\begin{array}{l}110-156 \\
\text { (if present) }\end{array}$ & \\
\hline Days on gluten before re-biopsy & 5 & 5 & 7 & 7 & 11 & 12 & 21 & 32 & & & \\
\hline
\end{tabular}

Table III Surface cell height, mucosal thickness, mitosis counts, villous height, and villous width before treatment shortly before and after gluten loading

$30 \mathrm{~g}$ gluten added to gluten-free diet in case 1 , and reversion to ordinary diet in the rest. The observations in brackets were not used for calculating the means, nor in the statistical analysis.

${ }^{1}$ No field suitable for mitosis count.

${ }^{2}$ Villi absent (counted as zero for height). 


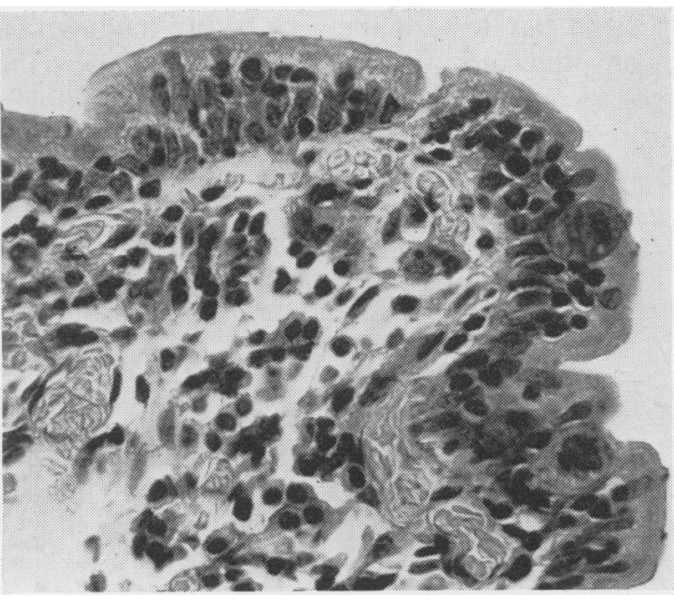

Fig. 5 Case 2 after three weeks gluten loading (ordinary diet), showing deterioration of surface cells with lymphocytes again visible. Surface cell height $19 \cdot 4 \mu(\times 160$, haematoxylin and eosin, $5 \mu)$.

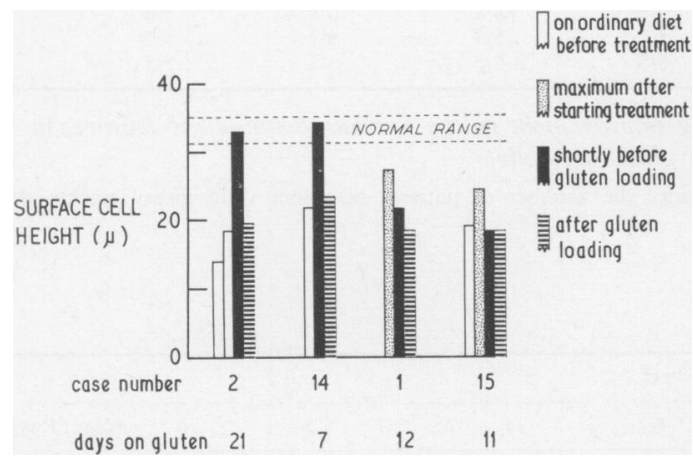

Fig. 6 Surface cell height before treatment, at its maximum after starting treatment, shortly before gluten loading, and after loading, in two patients with mucosa responding to a glutenfree diet (cases 2 and 14), and in two not responding (cases 1 and 15).

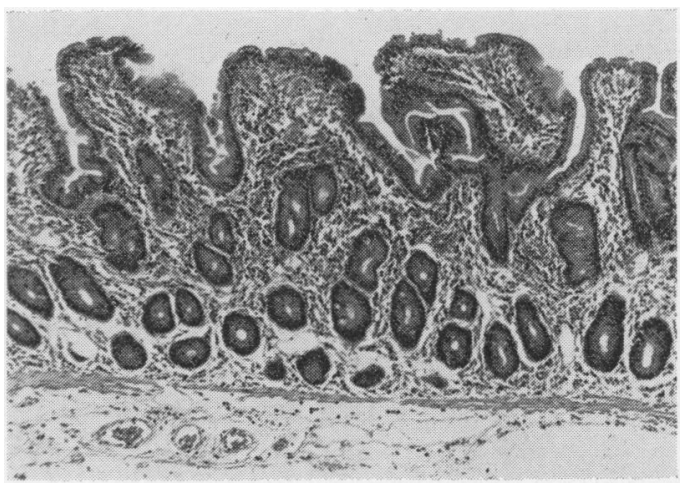

Fig. 7 Case 2, same biopsy specimen as in Figure 5. Villus-like projections are still present but shortened; the mucosa is again thick. Dissecting microscope appearance convoluted ridges. Mucosal thickness $260 \mu$, villous width $156 \mu$, villous height $242 \mu$ ( $\times 10$, haematoxylin and eosin, $5 \mu$ ). on a gluten-free diet and subsequent deterioration on gluten loading is illustrated in case 2 (Figs. 3, 4, and 7).

Crypt cells

Apart from the alteration in the number of mitoses the crypt cells, including the Paneth cells, showed no change.

\section{Inflammatory cells}

There was no increase in the number of plasma cells or eosinophils in the mucosa but an increased o number of lymphocytes appeared, passing $\vec{O}$ between the surface epithelial cells.

\section{Appearance of mucosal surface}

With the dissecting microscope the mucosa became more abnormal in two (leaf-like villi changing to convoluted ridges), but remained about the same in the other six (convoluted or 9 flat).

Summary of effects of gluten loading
In all eight patients studied the jejunal mucosa reverted, to a greater or lesser extent, towards its pretreatment state (Table III). In four patients the villous height was reduced, in five the villous width increased, and in six the surface cell height diminished. In five mitosis counts were higher.

\section{Discussion}

These results demonstrated the sensitivity of the jejunal mucosa to a gluten-free diet in all our patients with idiopathic steatorrhoea. No patient failed to respond in some measure, and the response was rapid for surface cell height, mitosis count, and (less frequently) for mucosal thickness (Table II). It was delayed, although in the end as $§$ frequent, for villous height and width. However, 0 although the items measured improved in most of the patients, only a minority of them returned to normal and in no patient did the mucosa become histologically normal in every respect. Bayless, o Yardley, Norton, and Hendrix (1962) found $N$ marked improvement in surface cell height in $\underset{\mathrm{C}}{\mathrm{N}}$ two patients after seven days on a gluten-free diet. Yardley et al (1962) found that it took several

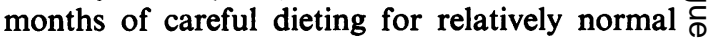
villi to reappear. Changes in the mucosa seen $\stackrel{\infty}{?}$ through the dissecting microscope, following 0 exclusion or inclusion of dietary gluten, were not as striking in our patients, as changes in histology and usually took longer to appear. Macroscopic- $\mathbb{\mathbb { D }}$ ally restoration of normal finger-like villi did $\bar{\sigma}$ not occur although leaf-like villi (not infrequently seen in patients without gastrointestinal disease) appeared in four cases.

The results also show how sensitive the jejunal mucosa was in these cases to dietary gluten introduced after a period on a gluten-free diet. In 
each of the eight patients loaded with gluten there was deterioration on nearly all the features measured. Furthermore the changes took place rapidly-within five days in cases 3 and 4 , and seven days in cases 5 and 14 ; in three of these four patients there was increase in villous width (marginal in one) and reduction in surface cell height, and in all four there was increase in mucosal thickness (Table III). Bayless et al (1962) found that in one patient whose mucosa after treatment was virtually normal the surface cell height reverted after six days of gluten loading to the pretreatment state, and the mitosis count trebled. Samloff, Kelly, Logan, and Terry (1964) described a patient who remained asymptomatic after returning to a normal diet but in whom the jejunal mucosa reverted to its pretreatment state. Rubin, Flick, MacDonald, and Parmentier (1961) demonstrated measurable histological changes in the ileal mucosa of two patients with idiopathic steatorrhoea within 12 hours of the instillation of gluten into the ileum.

It has been suggested that carcinoma outside the small intestine may be causally associated with jejunal mucosal atrophy (Creamer, 1966). The jejunal mucosa in our patient with carcinoma of the larynx (case 12) showed good responses both to a gluten-free diet and to gluten loading, strong evidence that, whatever the nature of the association between these two conditions in her case, she was certainly gluten sensitive.

Changes found on serial biopsy of our patients could not be explained by variations in the level at which the specimens were obtained for they were all taken from the upper jejunum.

It has been suggested (Frazer, Schneider, Morgan, and Sammons, 1964) that if idiopathic steatorrhoea is due to sensitivity to gluten, criteria for its diagnosis should reasonably include demonstrable improvement on a glutenfree diet, and deterioration on subsequent gluten loading. These dietary manoeuvres may not be easy to carry out and will usually be time consuming. Few patients may keep to the diet rigidly for a long period of time. In common with others we have found patients with this condition who are at least partially unresponsive to the diet (French, Hawkins, and Smith, 1957; Buchan, Marko, and Gerrard, 1958; Green, Wollaeger, Scudamore, and Power, 1959; Sleisenger, 1961; Cooke, Fone, Cox, Meynell, and Gaddie, 1963; Shiner, 1963; Bolt et al, 1964; Benson, Kowlessar, and Sleisenger, 1964; Stewart et al, 1967). Some of these patients probably failed to keep strictly to the diet. Steatorrhoea may be absent before treatment, and when present it is often so variable in degree that clinical and laboratory assessment must be continued for many weeks to measure response. Many patients and laboratories find numerous faecal fat estimations an intolerable burden. After gluten loading steatorrhoea may not reappear at once, or at all, and the patient's clinical state may sometimes be un- affected. Furthermore individual abnormalities improve on a gluten-free diet at different rates in different patients. Case 4 felt better, lost the $(\Omega$ steatorrhoea, gained $10.6 \mathrm{~kg}$ in weight, and the folic acid absorption became normal, but the $\overrightarrow{\vec{F}}$ glucose absorption improved very little. Case $6 \stackrel{\text { S9 }}{+}$ persisted with a gluten-free diet for many months? three times. She always felt better on it $\frac{\bar{O}}{\bar{N}}$ and gained weight (up to $5.5 \mathrm{~kg}$ ), but not until $\frac{\bar{\sigma}}{\sigma}$ the third attempt was steatorrhoea lost; even $\varnothing$ then folic acid absorption was only slightly ${ }_{\infty}$ improved and daily faecal weight remained high $\vec{\circ}$ at 300 to $800 \mathrm{~g}$ per day (normal 60 to $250 \mathrm{~g}$; Harrison, 1957).

Some of these variable results and some of the $\stackrel{\Omega}{\Omega}$ histological findings may have been due to our

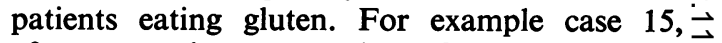
after seven days on a gluten-free diet, showed $\vec{v}$ considerable improvement in measurements of surface cell height, mucosal thickness, and mitosis count, but after 113 days the mucosa was as bad or worse in each respect as it was before treatment, and the dissecting microscope appear- $\frac{\complement}{\bar{\zeta}}$ ances never improved. Perhaps significantly this $<$ patient's mucosa showed no change of any kind $\vec{\varphi}$ on subsequent gluten loading. One patient (case. 17) showed little response over a long period. The fact that in cases 12 and 15 improvements were seen in biopsy specimens seven days after starting a gluten-free diet suggests that lack of improvement after longer periods was not neces- $\mathbb{Q}$ sarily due to inadequate time on the diet. In $\overrightarrow{\vec{\prime}}$ cases 1,3 , and 14 changes in histological features $\frac{\circ}{3}$ did not vary consistently with each other in the different treatment periods. Dietary lapses seem inadequate as an explanation of this finding. It is considerations such as these which probably $\subsetneq$ explain the variable histological results found by ourselves and previous workers.

It would clearly help to have a quick, reliable diagnostic test for indicating the presence of gluten sensitivity. Estimations of serum glutamine $\stackrel{\circ}{5}$ after gluten or gliadin loading do not yet provide $\frac{\square}{2}$ such a test (Weijers and van de Kamer, 1955 and 1959; Payne and Jenkinson, 1958). The results of $\mathcal{N}^{\circ}$ our work, and of others, suggest that if the patient can rigidly adhere to a gluten-free diet for about three weeks the presence or absence of $\mathrm{W}$ improvement in surface cell height, mucosal thickness, and mitosis count will be a reliable index of gluten sensitivity. Conversely, on biopsy after subsequent gluten-loading, deterioration of the mucosa may be obvious within a week (mainly in surface cell height and mucosal thickness). Observation of the changes described may be $\stackrel{\leftrightarrow}{\overparen{D}}$ particularly useful in clarifying aetiology in the $\triangle$ patient suffering from idiopathic steatorrhoea whose clinical state and steatorrhoea do not $\delta$ improve on a gluten-free diet. Such measurements may also be of value in elucidating the nature of jejunal mucosal changes in patients who have other disease (Townley, Cass, and Anderson, 1964; Johnstone and Adams, 1964; 
Creamer, 1964 and 1966; Gjone, Myren, and Refsum, 1965; Lee, 1966; Fry and McMinn, 1966; Marks, Shuster, and Watson, 1966; Shuster, Watson, and Marks, 1968).

We are indebted to $\mathrm{Dr}$ Q. J. G. Hobson for allowing us to study case 11 , and to Dr Leo Gilchrist of Farnborough Hospital, Kent, for referring case 16 and for giving us details of the case history. We thank Dr J. G. Selwyn for the haematological data; Dr F. M. Abeles and Dr D. H. Bodger for performing the barium examinations, and Professor D. L. Mollin, formerly of Hammersmith Hospital, for the estimations of serum concentrations of vitamin $B_{12}$ and folic acid. We are grateful to Miss Susan Robinson for her help with the chart.

\section{References}

Anderson, C. M. (1960). Histological changes in the duodenal mucosa in celiac disease. Reversibility during treatment with a wheat gluten free diet. Arch. Dis. Childh., 35, 419427.

Bayless, T. M., Yardley, J. H., Norton, J. H., and Hendrix, T. R. (1962). Adult coeliac disease: rapid sequential changes in jejunal mucosa with alterations of dietary gluten. J. clin. Invest., 41, 1344.

Benson, G. D., Kowlessar, O. D., and Sleisenger, M. H. (1964). Adult celiac disease with emphasis upon response to the gluten-free diet. Medicine (Baltimore), 43, 1-40.

Bolt, R. J., Parrish, J. A., French, A. B., and Pollard, H. M. (1964). Adult coeliac disease. Histologic results of longterm low gluten diet. Ann. intern. Med., 60, 581-586.

Buchan, D. J., Marko, A. M., and Gerrard, J. W. (1958). The malabsorption syndrome: its treatment with a gluten free diet. Canad. med. Ass. J., 79, 227-230.

Chacko, C. J. G., Job, C. K., Johnson, S., and Baker, S. J. (1961). Histopathological changes in the upper jejunum in tropical malabsorption syndrome. Studies by transoral biopsy. Indian J. Path, Bact., 4, 203-213.

Cooke, W. T., Fone, D. J., Cox, E. V., Meynell, M. J., and Gaddie, R. (1963). Adult coeliac disease. Gut, 4, 279-2S1.

Creamer, B. (1964). Malignancy and the small-intestinal mucosa. Brit. med. J., $2,1435-1436$.

Creamer, B. (1966). Coeliac thoughts. Gut, 7, 569-571.

Doniach, I., and Shiner, M. (1957). Duodenal and jejunal biopsies. II. Histology. Gastroenterology, 33, 71-86.

Doniach, I., and Shiner, M. (1960). Histopathology of the stomach in pernicious anaemia and jejunum in steatorrhoea. Brit. J. Radiol., 33, 238-242.

Frazer, A. C., Schneider, R., Morgan, D. B., and Sammons, H. G. (1964). Gluten-induced enteropathy and protein digestion. In Proc. 6th Internat. Cong. Nutrition, Edinburgh, 1963, p. 353, edited by C. F. Mills and R. Passmore. Livingstone, London.

French, J. M., Hawkins, C. F., and Smith, N. (1957). The effect of a wheat-gluten-free diet in adult idiopathic steatorrhoea. Quart. J. Med., n.s., 26, 481-499.

Fry, L., and McMinn, R. M. H. (1966). Morphology and functional cytology of the small intestinal mucosa in malabsorptive disorders and other diseases. J. clin. Path., 19, $260-265$.

Galen, E. H. (1962). Non-tropical sprue: reversal of proximal jejunal lesion in a patient treated with a gluten-free diet. Gastroenterology, 43, 465-471.

Gjone, E., Myren, J., and Refsum, S. B. (1965). Total jejunal villous atrophy in secondary steatorrhoea. Acta path. microbiol. scand., 65, 24-30.

Green, P. A., Wollaeger, E. E., Scudamore, H. H., and Power, M. H. (1959). Non-tropical sprue. Functional efficiency of small intestine after prolonged use of gluten-free diet. J. Amer. med. Ass., 171, 2157-2162.

Harrison, G. A. (1957). Chemical Methods in Clinical Medicine, 4th ed. Churchill, London.

Holmes, R., Hourihane, D. O'B., and Booth, C. C. (1961). Dissecting microscope appearances of jejunal biopsy specimens from patients with 'idopathic steatorrhoea'. Lancet, 1, 81-83.
Johnstone, J. M., and Adams, J. F. (1964). Jejunal mucosal appearances after total gastrectomy. Gut, 5, 60-63.

Lee, F. D. (1966). Nature of the mucosal changes associated with malignant neoplasms in the small intestine. Gut, 7, 361-367.

MacDonald, W. C., Brandborg, L. L., Flick, A. L., Trier, J. S., ? and Rubin, C. E. (1964). Studies of coeliac sprue. IV. The response of the whole length of the small bowel to a gluten-free diet. Gastroenterology, 47, 573-589.

Marks, J., Shuster, S., and Watson, A. J. (1966). Small bowel $\stackrel{\mathcal{C}}{+}$ changes in dermatitis herpetiformis. Lancet, 2, 1280-1282.

Paulley, J. W. (1954). Observations on the aetiology of idiopathic steatorrhoea. Jejunal and lymph node biopsies. Brit. med. J., 2, 1318-1321.

Payne, W. W., and Jenkinson, V. (1958). A test for coeliac disease. Arch. Dis. Childh., 33, 413-416.

Rubin, C. E. (1960). Celiac disease and idiopathic sprue. Some reflections on reversibility, gluten and the intestine. Gastroenterology, 39, 260-261.

Rubin, C. E. (1961). Malabsorption: celiac sprue. Amer. Rev. Med., 12, 39-54.

Rubin, C. E., Flick, A. L., MacDonald, W. C., and Parmentier, C. M. (1961). Acute intestinal response to wheat in coeliac sprue. Clin. Res., 9, 89.

Samloff, I. M., Kelly, M. L., Logan, V. W., and Terry, R. (1964) Severe histopathological lesion of sprue in patient with minimal evidence of malabsorption. Serial jejunal biopsy and clinical observations. Ann. intern. Med., 60, 673-679.

Shiner, M. (1963). Effect of a gluten-free diet in 17 patients with idiopathic steatorrhoea. Amer. J. dig. Dis., 8, 969-983.

Shiner, M., and Doniach, I. (1958). Histopathologic studies in steatorrhoea. In Proceedings World Congress of Gastroenterology, vol. 1, pp. 586-607. Williams and Wilkins, Baltimore.

Shuster, S., Watson, A. J., and Marks, J. (1968). Coeliac syndrome in dermatitis herpetiformis. Lancet, 1, 1101-1106.

Sleisenger, M. H. (1961). Clinical and matabolic studies in nontropical sprue. New Engl. J. Med., 265, 49-56.

Stewart, J. S., Pollock, D. J., Hoffbrand, A. V., Mollin, D. L. and Booth, C. C. (1967). A study of proximal and distal intestinal structure and absorptive function in idiopathic steatorrhoea. Ouart. J. Med., 36, 425-444.

Townley, R. R. W., Cass, M. H., and Anderson, C. M. (1964). Small intestinal mucosal patterns of coeliac disease and idiopathic steatorrhoea seen in other situations. Gut, 5 , 51-55.

Weijers, H. A., and Van de Kamər, J. H. (1955). Coeliac disease VI. A rapid method to test wheat sensitivity. Acta paediat (Uppsala), 44, 536-540.

Weijers, H. A., and Van de Kamer, J. H. (1959). Coeliac disease VII. Application and interpretation of the gliadine tolerance curve. Acta paediat. (Uppsala), 48, 17-24.

Yardley, J. H., Bayless, T. M., Norton, J. H., and Hendrix, T. R. (1962). Coeliac disease. A study of the jejunal epithelium before and after gluten-free diet. New Engl. J. Med., 267, 1173-1179.

\section{Statistical appendix}

\section{P. MACDONALD \\ From Brunel University, Uxbridge, Middlesex}

The biopsies were taken in three treatment periods, I, II, and III, as well as in the pretreatment period, $P$, and in the gluten loading period, $G$. The changes in the mucosa were analysed for the intervals from $P$ to each of I, II, III, and G; from I to II; and from III to G. None of the patients had a biopsy in every one of the five periods and some patients had more than one biopsy in a given period. These replicates were deleted so that, at most, one biopsy was recorded in each period, the dates being chosen so as to equalize the time intervals as much as possible.

The changes in the mucosa over the various intervals were analysed separately and each average change between two time periods was tested for significant difference from zero by use 
of the $t$ distribution. In each test the average change was calculated using all the data that were available for that comparison. Single-tailed tests were used throughout as there was prior knowledge about the direction of possible change in each case.

\section{Results}

\section{SURFACE CELL HEIGHT}

The initial average increase in height after one period of treatment was $6.56 \mu(\mathrm{P}<0.001)$. There was no significant change from periods I to II but the overall increases from pretreatment to period II and to period III were both significant, being $6.23 \mu(0.02<P<0.05)$ and $10.68 \mu(\mathrm{P}<0.001)$ respectively. Gluten loading resulted in a significant decrease of $5.50 \mu$ $(P<0.01)$, but the mean height was then still greater by $3.50 \mu$ than before treatment with a gluten-free diet, averaged over cases $2,3,4,5$, 14 , and 15.

\section{MUCOSAL THICKNESS}

There were significant decreases in thickness from pretreatment to period II of $103.7 \mu$ $(\mathrm{P}<0.02)$ and to period III of $135.8 \mu(\mathrm{P}<$ $0.001)$. Gluten loading resulted in a significant increase in thickness of $50.1 \mu(P<0.01)$, but the thickness was still $102.5 \mu$ less than before treatment with a gluten-free diet, averaged over cases $2,3,4,5,14$, and 15 .

\section{MITOSIS COUNT}

The observed decreases in the count from pretreatment to treatment periods I, II, and III were $0.67(0.02<\mathrm{P}<0.05), 0.43(\mathrm{P}<0.01)$ and $1.75(0.02<\mathrm{P}<0.05)$ respectively. There was no evidence that gluten loading reversed the decrease over the time intervals used.

VILLOUS HEIGHT

Treatment significantly increased the villous height by about $207 \mu \quad(0.01<\mathrm{P}<0.02)$, averaged over cases $2,3,4,5,14$, and 15 , whereas. the average decrease of $39.6 \mu$ following gluten $\vec{\omega}$ loading was only weakly significant $(0.05<$ $P<0 \cdot 10)$.

\section{Comment}

It should be noted that the estimated changes from one period to another do not add up because $\subseteq$ of random fluctuations and because biopsies could not be taken from all patients in all treat- $\vec{c}$ ment periods. The analysis, based on pair-wise. comparisons, was found to be adequate so that $O$ it was decided not to extend the analysis to simultaneous comparisons allowing for correlated observations and actual biopsy dates. The various $t$ tests made were not all independent but this did not interfere with the interpretation of the results. 